\title{
TOPOGRAPHIC EXPOSURE AND ITS PRACTICAL APPLICATIONS
}

\author{
TOMÁŠ MIKITA, MARTIN KLIMÁNEK
}

\begin{abstract}
Department of Geoinformation Technologies, Faculty of Forestry and Wood Technology, Mendel University in Brno, Zemédělská 3, 61300 Brno, Czech Republic, E-mail: tomas.mikita@mendelu.cz, klimanek@mendelu.cz, Phone: +420 545134 021, +420545134017
\end{abstract}

Received: $16^{\text {th }}$ April 2010, Accepted: $13^{\text {th }}$ July 2010

\begin{abstract}
Topographic exposure is a topographic characteristic representing a degree of protection by a surrounding topography of a certain site. Detailed knowledge of topographic exposure has broad use in a number of applications ranging from studying forest wind damage through research on snow storage dynamics to optimisation in positioning wind power stations. This paper describes a method for creation of topographic exposure on the basis of a digital elevation model (DEM) using GIS. In combination with other climatic data on wind direction and speed, this factor is used to define the degree of terrain ventilation. Low terrain ventilation has, among other things, a significant influence on the creation of valley inversions and related vegetation zoning inversions. By combining the degree of terrain ventilation with DEM and forest vegetation zones in the area of the Training Forest Enterprise Krrtiny, a clear relationship between the influence of topographic exposure, or terrain ventilation, and the creation of the vegetation zoning inversion was determined.
\end{abstract}

Keywords: DEM, GIS, hillshade, terrain ventilation, topographic exposure

\section{INTRODUCTION}

Topographic exposure is a geomorphometric feature of topography and characterises a site in terms of its protection by the surrounding landscape. Geomorphometry is a general scientific field that deals with topographic quantification of the landscape on the basis of digital elevation models (Pike et al., 2008). The degree of a topographic exposure of a site is dependent on the relative height and distance of the surrounding horizon. According to Ruel (1995), the topographic exposure on a given site is equal to the sum of all vertical angles to the horizon in 8 basic directions to the cardinal points.

The topographic exposure factor is used mostly for the purposes of evaluating threats to forest stands from wind and is mentioned and used in this context in a number of studies (Lanquaye et Mitchell, 2005; Ruel et al., 2002; Scott et Mitchell, 2005). It is, however, applied also in the area of meteorological phenomena modelling (Chapman, 2000), monitoring the impact of wind on railway tracks (Baker, 1985), or determining the potential availability of the GNSS signal (Mikita et Klimánek, 2010). Despite a number of published studies, specific methods for calculating in the GIS environment are not described in any of the publications. Theoretically, it is possible to model this feature by analysing visibility from a regular network of points with settings of a specific direction (search area) 
(Kuchyňková et Mikita, 2010). This method, however, is enormously demanding on a computer computational capacity and requires additional adjustments to the results achieved. A specific freely available algorithm for calculating topographic exposure is available from the Harvard University website. The model entitled EXPOS (Boose et al., 1994) was created to predict the impacts of hurricanes in the United States and is implemented into the IDRISI software environment. The principle of the model is shown in Figure 1.

Fig. 1: Classification of terrain according to exposure to certain direction of wind ( $\theta$ vertical angle - inflection angle) (Boose et al., 1994).

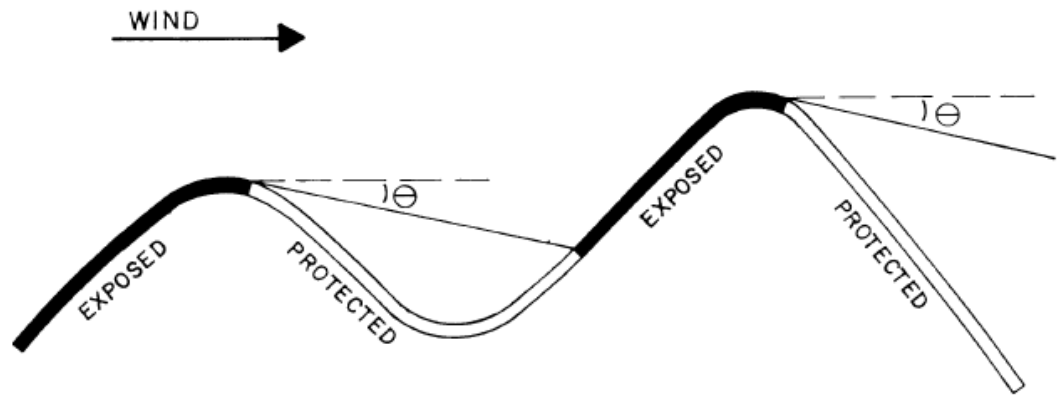

\section{MATERIAL AND METHODS}

The aim of this article is to describe an easy creation of topographic exposure factor in the GIS environment on the basis of digital elevation models. DEMs present an interpretation of the actual terrain of a particular site in digital form in various data representations and they are both a source of precise basic numerical (morphometric) data for the area as well as a useful tool for its graphic presentation. The digital nature of the DEM data (especially in raster form) then makes it possible to carry out other diverse statistical analyses above and beyond the DEM derivatives (Kolejka et al, 2009).

The accuracy of digital elevation models for the Czech Republic is given by the precision of the hypsometric base used. At present, the most widespread and most commonly used source of data is the contour lines of the ZABAGED primary geographical database created by the stereophotogrammetric processing of aerial photographs as part of military topographic mapping during 1952-1957. The mean altitude error of the data reaches $0.7-1.5$ metres in bare terrain, 1-2 meters in urban areas and 2-5 metres in forested areas (Brázdil, 2009). The aforementioned accuracy is more than sufficient in the case of surveying the topographic exposure at the level of macro- to mezo-topography. In the near future, however, planned laser scanning of the topography of the Czech Republic will even further multiply the opportunities for the use of DEM in various analyses.

The area of interest for testing the calculation of topographic exposure was the Training Forest Enterprise Masaryk Forest Krrtiny of Mendel University in Brno (hereinafter just "TFE"). TFE is located in a rugged terrain of the surroundings of the Svitava River, north to north-east of the city of Brno at an altitude of 212-574 metres above the sea level, and it comprises of forest stands with an area of over 10,000 ha. The basic material for the calculation was the digital elevation model with the resolution of 10 metres derived from 
the ZABAGED contour lines using the Topo To Raster tool. This tool creates a so-called hydrologically correct model and reaches the best results from the available interpolation tools for contour lines data (Klimánek, 2007).

The topographic exposure may be modelled very effectively using the shaded topography. Calculation of the shaded topography (hillshade) is an integral part of most GIS applications, and it was completed in particular using the ESRI ArcGIS 9.3 software. To calculate the hillshade, the Hillshade tool of the extension Spatial Analyst was used. This tool creates a hypothetical illumination of the topography and, based on the setting of a hypothetical light source position, calculates the illumination level for each pixel depending on its surroundings between the values of $0-255$. The parameters during setting also include the horizontal angle of the direction of the illumination in the form of the azimuth to north and the vertical angle from the horizontal plane. The baseline values during normal processing of the shaded topography for the DEM presentation are a vertical angle of 45 degrees and a horizontal angle of 315 degrees (corresponding to the illumination from northwest). The algorithm for calculating illumination has the following formula (www.esri.com, 2010):

\section{Hillshade $=255 *((\cos Z * \cos S)+(\sin Z * \sin S * \cos (A z-A s)))$,}

where $\mathrm{Z}$ is the zenithal angle in radians, $\mathrm{S}$ is the slope gradient in radians, $\mathrm{Az}$ is the azimuth in radians and As is the slope exposure in radians.

For the purposes of evaluating the impact of wind, it is possible to choose a value of $5^{\circ}$, which corresponds with data from foreign literature (Boose et al., 1994).

The shaded topography calculated by using the aforementioned method expresses the topographic exposure of a site from a given direction. For comprehensive evaluation of topographical exposure in an area, it is necessary to repeat this method for a minimum of the 8 directions of the cardinal and ordinal points (N, NE, E, SE, S, SW, W, NW), then reclassify all generated rasters to two categories $(0$ - unexposed, 1 - exposed pixels) and subsequently summarise to the form of the final topographic exposure map. High values of the resulting summary raster indicate a high level of topographic exposure and vice versa. The precision of the final map is also influenced by the number of chosen directions. More precise values can be acquired for example from 16, 32 or more directions.

For simplification, the calculation was processed into the form of Toolbox for ArcGIS 9.3, which, after entering the input DEM, enables the direct calculation of topographic exposure from 8 directions without having to re-enter the input data in batches. The results confirm the functionality of the tool. In accordance with expectations, the most exposed are mild slopes and plateaus and the least exposed, on the other hand, are deep valleys with steep slopes (see Figure 2).

\section{Practical application of topographic exposure}

In addition to the aforementioned common use in creating forest wind risk models, the factor has a number of other applications of which we will focus primarily on terrain ventilation and vegetation zoning inversion.

\section{Terrain ventilation}

Topographical configuration significantly affects air flow in the lower atmosphere and remarkably influences alterations in its direction and speed. Due to the influence of topography on the action of the wind, wind flow increases in certain places, while in others, by contrast, wind-protected sites are created. Although wind activity in rugged terrain is 
influenced by a number of factors such as surface roughness, specific type of flow (laminar vs. turbulent), and changes in direction and speed due to obstacles, the prevailing direction as well as the average speed at a particular site can be determined using mathematical models (e.g. PIAPBLM - developed by the Institute of Atmospheric Physics, Academy of Science of the Czech Republic (Svoboda et al., 2008), WaSP - Riso Laboratories, Technical University of Denmark (Mortensen et al., 1998)).

On the basis of the topographic data and wind direction and speed in the region, it is possible to define the so-called terrain ventilation or geo-relief ventilation. According to Kolejka et al. (2009), terrain ventilation is a relative feature related solely to the wind direction regardless of its duration. This means that the values of terrain ventilation can be both immediate, i.e. calculated to a specific wind direction at a given time, and long-term, or related to long-term directional characteristics of the wind, e.g. to the most frequent wind direction measured in individual sectors of the compass rose, the long-term most frequent wind direction calculated according to the sector of the most frequent direction and the frequencies of neighbouring directions, whether daily, monthly, annual or other long-term values of wind direction have been taken into consideration (Kolejka et al, 2009).

The extent or degree of geo-relief ventilation can be described using the values of the socalled coefficient of the effective terrain ventilation (Blazejczyk, 1975). This is calculated for individual segments of the axis intersecting the contour lines in the selected area. The calculation is based on the determination of the width of the valley bottom and the width and depth of the valley (it may, however, involve any shape of topography). The calculation proceeds from the lowest positions upwards. The calculated values of the coefficient are always relative to the "increase" in the width of the valley compared to the width of the valley bottom. The depth of the valley can be the vertical separation of contour lines, while the "width of the valley" from the previous step of the calculation becomes the width of the valley bottom. The lowest values in the outcome are in the middle of the valley (i.e. at the "bottom") and then increase approximately symmetrically towards the actual edges of the valley with increasing distance from the bottom (Kolejka et al, 2009).

Implementation of this procedure into current GIS applications is, however, very difficult and requires a greater familiarity with working in GIS, including scripting. An alternative method of calculating the terrain ventilation was carried out by combining the data on topographic exposure with the data on wind direction and speed for the entire territory of the Czech Republic. The data source on hypsometry of the territory of the Czech Republic was the DEM publicly available on the website of ArcData Praha s.r.o. with a resolution of about 60 metres. This model of the topography of the whole world was created through tessellation and adjustment of data taken during the Shuttle Radar Topography Mission (SRTM) of the space shuttle Endeavour (www.arcdata.cz, 2010). Because original resolution of DEM from SRTM is not strictly quadrangle (different resolution in latitude and longitude), final DEM was re-sampled to 100 meters. Wind speed was determined on the basis of data from the Institute of Atmospheric Physics, Academy of Sciences of the Czech Republic, freely available on the map server geoportal.cenia.cz. The problematic transfer of data on wind direction from wind roses for the main stations was carried out on the basis of digitisation of the locations of the stations and by subsequent surface interpolation of data on annual frequencies of the duration of wind direction using the IDW (Inverse Distance Weighted) interpolation tool for each of the 8 basic directions. A total of 8 raster layers indicating area-wide the frequency of duration of a particular wind direction in a given pixel were thus created. Although this procedure is not very objective (wind direction changes occur locally due to topography), in terms of availability of the source data it is practically the only procedure possible. 
Fig. 2: Section of topographic exposure map in TFE Křtiny (material: DMÚ 25; source: geoportal.cenia.cz)

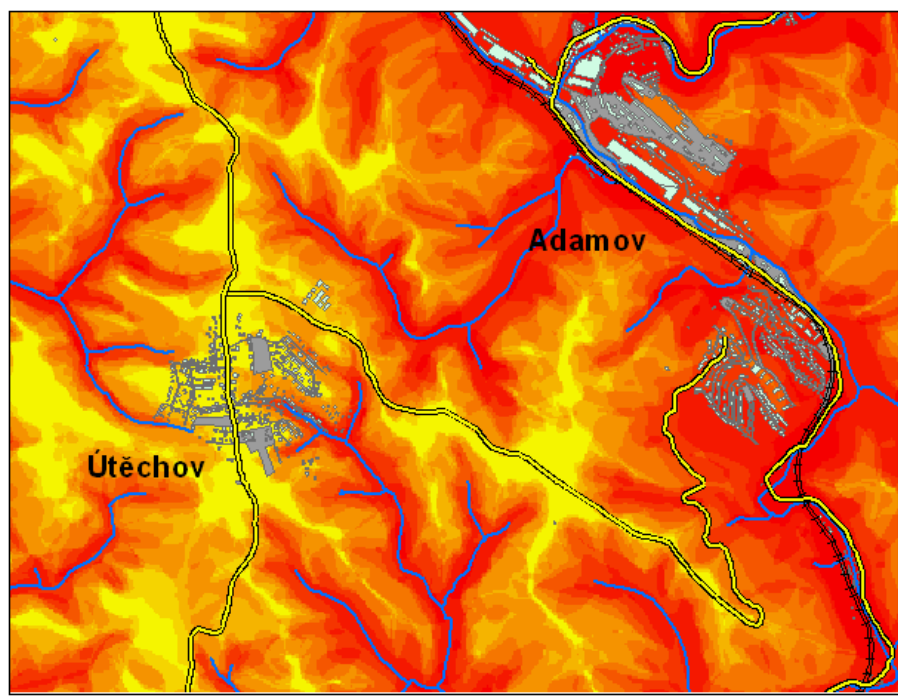

Topographic exposure

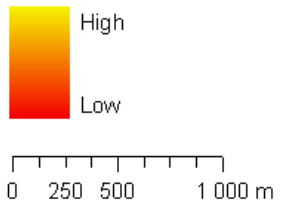

Fig. 3: Terrain ventilation in the Czech Republic calculated according to the aforementioned procedure.

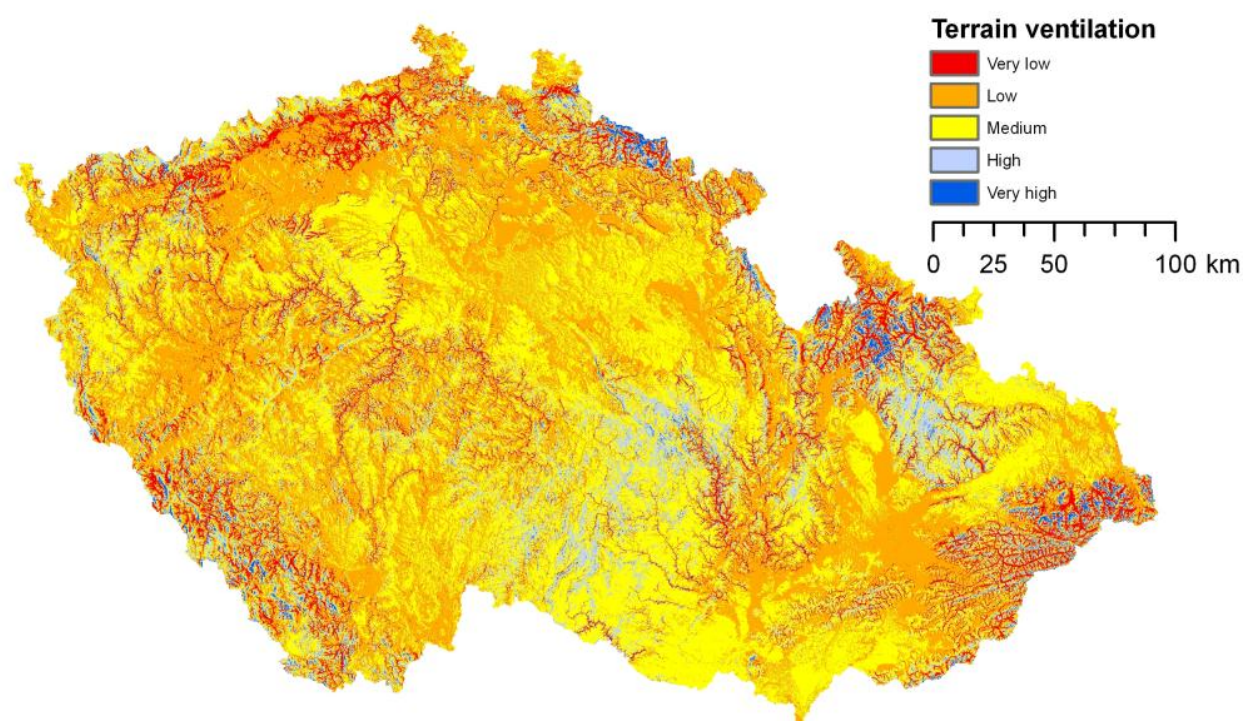

The resulting map was created by a weighted sum of rasters (partial shaded topographies multiplied by the frequency of wind direction) multiplied by the wind speed. In detail, e.g. hillshaded relief from the northeast was multiplied by percentage of the northeast wind duration and again multiplied by the average annual wind speed. This procedure was 
repeated for all of 8 basic directions and then all layers were summarized to the form of the final terrain ventilation map (see Figure 3).

In a detailed look at the terrain ventilation map, it is clear that the chosen method achieves quality results. In accordance with expectations, the most exposed, or ventilated, are mountain peaks and ridges, while peaks in highlands are less so and, by contrast, sites in deep valleys are the least ventilated ones.

\section{The influence of terrain ventilation on the creation of inversion vegetation zoning}

Vegetation zoning in a given area is a subject to a number of factors, of which climate, as determined by temperature and precipitation, plays the most important role. These climatic factors are mainly influenced by topography and altitude above the sea level. With increasing altitude above the sea level, the intensity of solar radiation increases by about 10 $\%$ per kilometer, while the temperature decreases (by $0.54{ }^{\circ} \mathrm{C}$ per $100 \mathrm{~m}$ ) and the amount of precipitation increases. Unlike temperature, however, changes in the amount of precipitation are remarkably of a regional character and are more influenced by the configuration of topographies in the direction of the prevailing arrival of weather fronts. This gives rise to significant differences between windward and leeward hill slopes in the form of precipitation shades. Compared to temperature, neither are there any significant differences between valleys and the surrounding peaks. These changes in directly acting environmental factors on vegetation cause the living conditions for vegetation from the lowlands to the mountains in the same area to change, which is reflected in its composition (Randuška et al., 1986). In the Czech Republic, there are, according to Zlatník, vegetation zones named after representation or dominance of major tree and bush species, and thus not after their optimum appearance in vegetation zones: 1. oak, 2. beech-oak, 3. oak-beech, 4. beech, 5. fir-beech, 6. spruce-beech-fir, 7. spruce, 8. dwarf pine, 9 alpine meadow, 10. subnival, and 11. nival (Zlatník, 1978).

The topography causes cold air to flow down and accumulate, mainly during the night, particularly in deep closed valleys, i.e. in areas without adequate ventilation (Zlatník, 1978). Due to this so-called climatic inversion, vegetation zoning thus is inverted especially at the bottoms of valleys and on north-facing slopes. This phenomenon makes the spatial analyses of vegetation zones rather difficult.

The influence of terrain ventilation on the inversion of forest vegetation zones (FVZ) has been studied again in the area of TFE Krrtiny with dependence on the above-sea-level altitude of the area. In the TFE area, a total of 5 forest vegetation zones $\left(1^{\text {st }}\right.$ to $5^{\text {th }} \mathrm{FVZ}$, see Table 1) were differentiated.

Table 1: Prevalence of forest vegetation zones in TFE Křtiny

\begin{tabular}{|c|c|}
\hline Forest vegetation zone & Representation (\%) \\
\hline 1. oak & 4.04 \\
\hline 2. beech-oak & 26.94 \\
\hline 3. oak-beach & 51.65 \\
\hline 4. beech & 17.32 \\
\hline 5. fir-beech & 0.04 \\
\hline
\end{tabular}

By combining the values of the terrain ventilation, altitude, and FVZ, a matrix table was created and the values were then analysed using multivariate regression in the program Statistica 8. Multivariate regression analyses several variables, when the focus is on the relationship between a dependent variable and one or more independent variables. More 
specifically, regression analysis helps us understand how the typical value of the dependent variable changes when any one of the independent variables is varied, while the other independent variables are held fixed. Most commonly, regression analysis estimates the conditional expectation of the dependent variable given the independent variables - that is, the average value of the dependent variable when the independent variables are held fixed (Zlatník, 1978). Although the resulting regression model reaches only minor significance $\left(\mathrm{R}^{2}=0.41\right)$, the impact of ventilation on FVZ prevalence is clearly demonstrated by linear interlay of the values from Graph 1.

The ventilation rate reduces the forest vegetation zone at a given altitude. Areas with low level of ventilation thus directly identify the inverse positions in deep valleys oriented vertically to the direction of the prevailing wind. Relatively little importance of regression is given by the dependence of FVZ on a number of other factors such as exposure, gradient and curvature of the topography, global radiation and distribution of rainfall. More precise results are presented in Graph 2, where the spline interlay of input values is used. Locations with high terrain ventilation can be described with steeper linear dependence of FVZ on the altitude then locations with low ventilation. That's why this kind of interlay defines the relationship between the assessed factors more accurately. This analysis shows the relevance of the ventilation factor and will be further developed in connection with the automated detection of forest vegetation zones using multidimensional statistical methods.

\section{CONCLUSION}

Topographic exposure as a factor indicating protection or exposure of a given site by the surrounding topography is applied in a series of analyses of landscape structures. The results of the chosen procedures using shaded topography clearly demonstrate the suitability of the selected methodology for calculating this factor. The procedures described allow an easy implementation of the calculation also in other raster-based GIS software. However, results of multivariate regression are not exactly clear; nevertheless topographic exposure expresses high dependence to the climatic inversion. The follow-up applications in the form of the terrain ventilation map clearly identify location with higher or lower ventilation. These result can be further modify for different practical purposes. Modified map could subserve in forestry for forest vulnerability evaluation against strong winds, in insurance industry for insurance events prediction or in landscape planning for identification of inverse positions. Therefore topographic exposure and its applications will be used in follow-up research in combination with other environmental factors for different landscape analysis. 
Graph 1: Dependence of topographic exposure and altitude on the prevalence of forest vegetation zones (linear interlay)

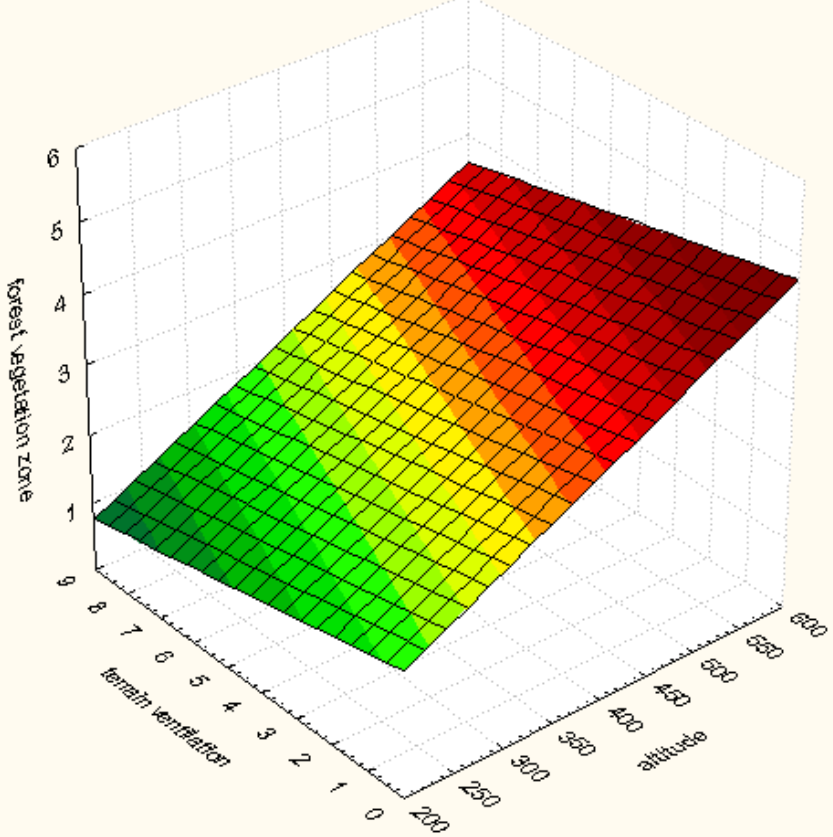

Graph 2: Dependence of topographic exposure and altitude on the prevalence of forest vegetation zones (spline interlay)

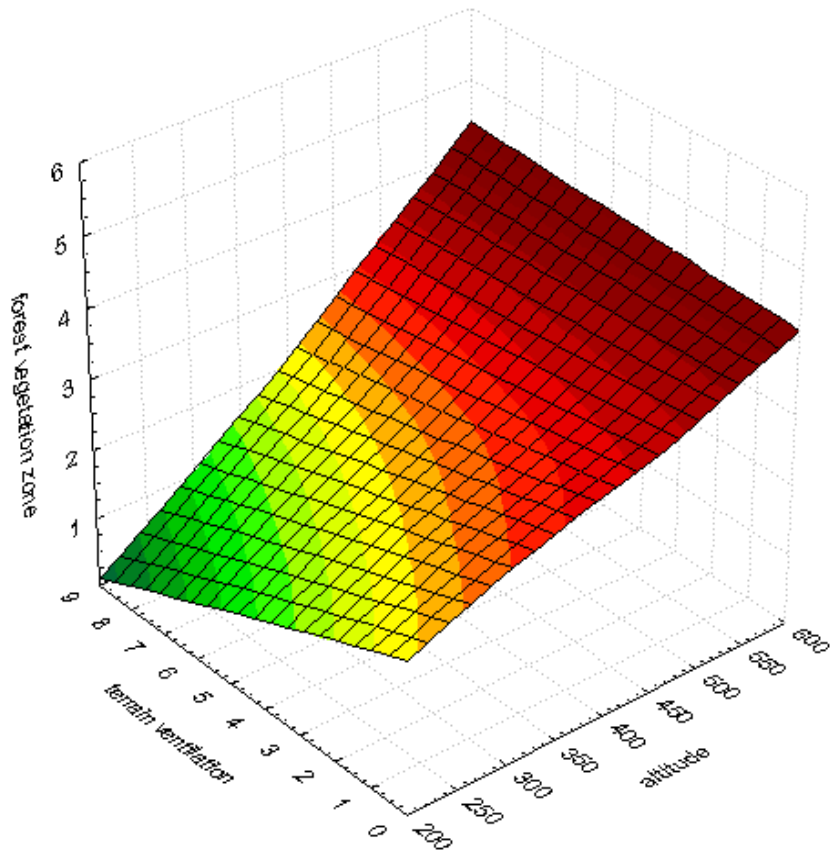




\section{ACKNOWLEDGEMENTS}

This article was produced as a part of the research project MSM 6215648902 "Forest and wood - support of functionally integrated forest management and the use of wood as a renewable raw material".

\section{REFERENCES}

ARCDATA (2010, February). Digitálni model reliéfu ČR. Retrieved 2010-02-15, from http://www.arcdata .cz/produkty-a-sluzby/eograficka-data/digitalni-model-reliefu-cr>.

Baker, C.J. (1985). The determination of topographical exposure factors for railway embankments. Journal of Wind Engineering and Industrial Aerodynamics, 21 (1), pp. 8999.

Blazejczyk, K. (1975). Wyznaczanie stopnia przewietrzania dolin. Przeglad geograficzny, roč. 47 , č. 1, s. 153-161.

Boose, E.R., Foster, D.R. \& Fluet, M. (1994). Hurricane Impacts to Tropical and Temperate Forest Landscapes. Ecological Monographs, Vol. 64, No. 4, pp. 369-400.

Brázdil, K. (2009). Projekt tvorby nového výškopisu území České republiky. Geodetický a kartografický obzor. č.7, Zeměměřický úřad, Praha, ISSN 0016-7096.

Chapman, L. (2000). Assessing topographic exposure. Meteorological Applications, vol. 7 , pp. 335-340.

ESRI (2009, February). How Hillshade works. Retrieved 2010-02-10, from http://webhelp.esri.com/arcgisdesktop/9.3/index.cfm?TopicName=How\%20Hillshade\%20 works>.

Klimánek, M. (2007). Přesnost digitálního modelu terénu a jeho využití v lesnictví. Acta Universitatis agriculturae et silviculturae Mendelianae Brunensis, sv. LV, č. 4, (p. 137144). ISSN 1211-8516.

Kolejka, J., Káňa, D., Plšek, V., Klimánek, M., Navrátil, V. \& Svoboda, J. (2009). Tématické mapy založené na digitálním modelu reliéfu. Geomorphologia Slovaca et Bohemica. sv. 9, č. 2 (p. 13-27). ISSN 1337-6799.

Kuchyňková, H., Mikita, T. (2008). Visual exposure within the Dolni Morava Biosphere Reserve. Journal of Landscape Ekology, Vol. 1, No. 2 (p. 67-79).

Lanquaye, C.O., Mitchell, S.J. (2005). Portability of stand-level empirical windthrow risk models. For. Ecol. Manage. 216, 134-148 .

Mikita, T., Klimánek, M. (2010). Mapa potenciální dostupnosti GPS signálu. Geodetický a kartografický obzor. č.3, Zeměměřický úřad, Praha, ISSN 0016-7096.

Mortensen, N.G., Landberg, L., Troen, I. \& Petersen, E.L. (1998). Wind Atlas Analysis and Application Program (WAsP) Vol. 1: Getting Started. Risø National Laboratory, Roskilde, 2 edition, 1998. Risø-I-666(v.1)(ed.2).

Pike, R.J., Evans, I. \& Hengl, T. (2008). Geomorphometry: A Brief Guide. In: Geomorphometry - Concepts, Software, Applications. In. Hengl, T., Hannes I. Reuter (Eds.), Series Developments in Soil Science vol. 33, Elsevier, pp. 3-33, ISBN 9780123743459.

Randuška, R., Vorel, J. \& Plíva, K. (1986). Fytocenológia a lesnícka typológia. Príroda. Bratislava, 339 s. 
Ruel, J.C. (1995). Understanding windthrow. Silvicultural implications. Forestry Chronicle 71: 434-444.

Ruel, J.C., Mitchell, S.J. \& Dornier, M. (2002). A GIS based approach to map wind exposure for windthrow hazard rating. Northern Journal of Applied Forestry. vol. 19, pp. 183-187.

Scott, R.E., Mitchell, S.J. (2005). Empirical modelling of windthrow risk in partially harvested stands using tree, neighbourhood and stand attributes. For. Ecol. Manage. 218, 193-209.

Svoboda, J., Mikita, T. \& Kolejka, J. (2008). Numerické modelování větru na Šumavě během orkánu Kyrill. In Klimánek, M. (Ed.) Geoinformačni podpora rozhodování v lesích postižených př́rodními pohromami. (p. 41 - 52). Brno: Mendelova zemědělská a lesnická univerzita v Brně, ISBN 978-80-7375-184-5.

Wikipedie (2010, February). Regression analysis. Retrieved 2010-02-15, from http://en.wikipedia.org/wiki/Regression_analysis>.

Zlatník, A. (1978). Lesnická fytocenologie. Státní zemědělské nakladatelství. Praha, 495 s. 